\title{
FLOWS, TRANSITS AND (DIS)CONNECTION POINTS: CONTRIBUTIONS TOWARDS A CRITICAL LUSOPHONY
}

\author{
Luís Cunha, Lurdes Macedo \& Rosa Cabecinhas
}

\begin{abstract}
As a concept, Lusophony is today looked upon with justified suspicion by many Portuguese-speaking people. It is impossible to separate this concept from the colonial ballast that bounds the countries that have Portuguese as the official language. However, it is important to not end the debate on this plane. In this work we revisit some of the foundational narratives of a mythical identity, such as the different hauntings of a promised Quinto Império or lusotropicalism, both in its founding in Brazil and in its reconstitution in Portugal. On the other hand, we discuss about Lusophony from its formal matrix: a language shared by different peoples in different continents. Our objective is to problematize and deepen the debate, summoning a unique experience of reflection, concretely the one that is elaborated by Jorge de Sena already in the final stretch of Estado Novo. Based on these focuses, we argue about the possibility of Lusophony to include lines of escape from certain reductionisms, namely those that derive from the convergent and divergent circulation of narratives and singular experiences. This circulation of people, ideas and memories, is potentially defining a diffuse and polycentric space of effective interculturality, which nurtures further reflection.
\end{abstract}

KEYWORDS

Lusophony; culture; interculturality; exceptionalism; singularity

\section{FLUXOS, TRÂNSITOS E LUGARES DE (DES)ENCONTRO: CONTRIBUTOS PARA UMA LUSOFONIA CRÍTICA}

\begin{abstract}
Resumo
Enquanto conceito, a lusofonia é hoje olhada com justificada desconfiança por muitos lusófonos. Sendo impossível desligar esse conceito do lastro colonial que liga os países que têm o Português como língua oficial, importa, no entanto, não encerrar o debate nesse plano. Neste trabalho revisitamos algumas das narrativas fundacionais de uma identidade mitificada, como são as diferentes assombrações de um prometido Quinto Império ou o lusotropicalismo, tanto na sua fundação no Brasil quanto na sua reconstituição em Portugal. Por outro lado, procuramos pensar a lusofonia a partir da sua matriz formal: uma língua partilhada por diferentes povos em diferentes continentes. Também neste ponto o nosso objetivo é problematizar e densificar o debate, convocando para tal uma experiência singular de reflexão, concretamente a que é elaborada por Jorge de Sena já na reta final do Estado Novo. Partindo dessas focalizações, argumentamos sobre a possibilidade de a lusofonia comportar linhas de fuga a um certo reducionismo crítico, nomeadamente as que decorrem da circulação, convergente e divergente, de narrativas e de experiências singulares. Esta circulação de pessoas, ideias e memórias é potencialmente definidora de um espaço difuso e policentrado de efetiva interculturalidade sobre o qual importa refletir.
\end{abstract}

Palavras-chave

Lusofonia; cultura; interculturalidade; excecionalismo; singularidade 


\section{UNIVERSALISM AND PARTICULARISM: FACETS OF CULTURE ${ }^{1}$}

While in the late 1950 saymond Williams (1958) showed conviction in discussing the cultural boundaries considering that the scope of a culture was generally proportional to a language's area, today such an association turns out to be unsustainable. Not only because English has gone beyond the extended boundaries where it has asserted itself as an official language, turning it into a sort of vulgar Latin of a new imperial cultural order, but also because the growing flow of people and ideas has shown that it is impossible to keep on believing in an idea that has always been an illusion: the conciliation between the political order, shaped in the sovereign State, and the cultural order, just as it was, and still is, envisaged by nationalism, being experienced by citizens coexisting in a territory which we have agreed to call nation. Obviously, this principle of segmenting culture, causing it to refer to a language or endowing it with an ethnic content, is, in itself, openly partial. In order to reestablish a distinction that Raymond Williams expounds upon as gain, it can be said that, when a language is set apart as noteworthy, we are favoring culture as a builder of distinct and potentially concurrent identities (Eagleton, 2000). However, this emphasis on particularism is just as successfully offset by an integrated understanding of culture, i.e., the vision of culture as the common product of a Humanity that progresses and develops in accordance with a goal that would ultimately amount to the victory of universal reason. This dichotomous and complementary vision of that which we call culture today appears to be too schematic and clearly insufficient to cope with the actual complexity of a concept that is too trivialized.

While fluctuating between the universal path, ensured by the conviction of a successful reason outlined by the enlightenment project, and the virtue of a disciplined ethnic distinction, i.e., contained within the borders of the various nation-states, the nationalist project appeared to ensure a firm balance point for all Humanity. Somehow, we were being offered was a chance to conciliate the great narrative, capable of formatting a World History from different change factors and records, with national narratives and even with more or less folkloric regional narratives. It was always a fragile and illusory balance, as well as a dangerous idealization, in whose name ethnic cleansings are legitimized, euphemistically considered a way of ensuring the preservation of national identities through an ideal of convergence between territory, people and culture.

In the latter half of the $20^{\text {th }}$ century, this entire fragile architecture of convenience came crashing down for good. The territories comprising European colonial empires became independent nations, which were also concerned with building their own legitimizing narrative (Chakrabarty, 2000). One of the aspects of that complex process of narrative construction is pointed out by Ferro (2004) who mentions that the history taught to African children tends to glorify the splendor of the great empires that existed on their continent prior to the arrival of the Europeans, by stressing that valuation of the past while offsetting it with the backwardness and decadence of feudal Europe from

\footnotetext{
' Research developed in the context of the project "Memories, cultures and identities: how the past weights on the presentday intercultural relations in Mozambique and Portugal?", supported by Aga Khan Development Network and Portuguese Foundation for Science and Technology.
} 
that same period. Additionally, this is a narrative strategy that was also highlighted in the analysis of the content of the history textbooks in current use in secondary education in Mozambique (see Cabecinhas, Macedo, Jamal \& Sá, 2018). Alongside this exercise of identity self-construction, migratory flows (both to old metropolises and to other countries with heightened economic growth) produced a diverging, let alone contradictory, effect. In fact, particularly after World War II and, to a large extent, during the emergence of new independent states, we witnessed increased migratory flows that gave larger European cities a facelift. What came across as exoticism to some and cosmopolitanism to others expressed a new atmosphere that inevitably diverged from the ideal of cultural homogeneity of nations (Portes, 2006) and, in that regard, contributed toward deconstructing the idea of a perennial identity associated with national culture.

The old metropolises' responses to this growing ethnic recomposition of their populations were different, are mapped out between two extremes: on the one hand, the quest for assimilationistic dynamic, hinged on an idea of supported integration, ultimately on the belief of the West's civilizational superiority; on the other hand, the idea of cultural relativism was taken as a reference to public policies, which ended up leading to what could be called functional multiculturalism. In a necessarily simplified way, the former case shows the French solution, while the English solution is shown in the latter case; however, in either case, including the more outlined proposals, the idea was to respond to post-colonial challenges. The difficulties Europe currently faces appear to show that neither solution was able to suitably resolve such challenges. In the last few decades, secular and republican France has dealt with what appears to be a setback in the process of integrating its immigrants, while British cultural relativism has turned out to be a "plural monoculturalism" (Sen, 2007), always subject to the outbreak of fundamentalisms within its midst.

Beyond the European space, and indeed outside this more immediately post-colonial equation, the U.S. represents a particular case. Its process of incorporation as a State, marked by a liberal consensus surrounding the idea of citizenship and democratic participation, singled out this territory not only relative to other former European colonies, but also in relation to its European counterparts from that same period (Catroga, 2005). This unique case with obvious consequences on how we deal with the issue of cultural diversity, to the extent the aggregating element, that which we can call the American way of life, manages the multiple ways of life typical of contemporary America, considering more ideals of abolishing differences than ideals of valuing diversity (Beck, 2006). Naturally, this unique and unrepeatable means should not be mistaken for the absence of conflict between ethnic and cultural roots. By contrast, also in this case the processes of integration and ethnic distinction were complex and generated tension, despite showing significant structural differences with those shown in the European context (Wacquant, 2014).

Portugal went also through a lengthy colonial experience that deeply structured many of the narratives that got us thinking as a nation and which still remain relevant in the post-colonial period in which we live today. One of the recurring vectors of these 
narratives was the assertion of an exceptionality almost always seldom discussed or examined. While we will come back to this issue later on, it's important, in this regard, to summon an expressive content, which is both an idea and a project at the same time: Lusophony. When discussing this, we will seek to focus the debate on the way a few central topics to the argument of exceptionality were readjusted to the post-colonial reality; this will enable us to think through the dynamics and traumas that mark Lusophony as a project.

\section{LUSOPHONY: FROM THE CONCEPT TO ITS IMPLEMENTATION}

First of all, it must be made clear that Lusophony has been commented in different tones and modelings. A single word entails very different understandings, which could range from those that regard Lusophony as a neocolonial threat in a world thought to be post-colonial, to those who look at it as a pragmatic project for expanding international possibilities of a language common to several countries (Cunha, 2015a). Between these two extremes, which project the same concept in a maximalist or minimalist line, we outline a wide range where different individual and institutional players meet, constituting a debate comprising various analytical centralities that either are excluded and clash, or strategically converge. These different centralities arise from engaging distinct disciplinary traditions and subsequent dispute surrounding the borders that delineate scientific fields, along with a relevant political inscription also fragmenting the object - on the one hand, associating it with a long tradition that essentializing the exceptionality of Portuguese colonialism; on the other, critically deconstructing the concept of Lusophony, ultimately suggesting that it be rejected. These conceptual confrontations somehow turn Lusophony into a useful category for thinking through ideas of culture and cultural diversity in late modernity.

In this regard, while seeking to turn this work into yet another piece for the lengthy debate we have just convened, we intend to think through Lusophony as a diffuse and avowedly conflicting category, not to position ourselves in any of the debate's central pillars; rather, by contrast, for us to try to explore its interstices as vanishing points. While the centrality of language in any Portuguese-speaking project is unquestionable, the truth is that ideological tension hampers any ambition of neutrality in this field. It is, therefore, important to qualify the confrontation. To the notion that Lusophony is a hierarchy-free forum, provided by the virtues of intercultural communication, we should add the proof that there is always power asymmetries involved in relations among social groups and among the cultural values that shape them (Cabecinhas \& Cunha, 2017; I. Macedo, 2013). On the other hand, while not denying the historical ballast produced by the colonial process, not allowing its scars to hinder the outlining of spaces where ideas a unique experiences can be exchanged, either converging or diverging, always adding something toward a common enrichment. In order to better situate it in the present, it's always possible and useful to make an archeology of confrontation and convergence of 
defining narratives, in the condition of resisting simplification and schematics ${ }^{2}$. Likewise, a few unique experiences have left a trail that should be reclaimed, also without doing away with a critical view or giving in to simplification. This point is precisely where we will begin, so that we can then deal with the persistence of a few defining narratives. In both cases, ours is a basically illustrative intention that does not allow a systematic reading.

\section{Jorge de Sena AND THE “CUlture OF LANGUAGE”}

It was toward the end of the Estado Novo [New State] regime, in July 1972, that Jorge de Sena, during his work visit to Mozambique, made public comments on the issues being dealt with here. For starters, it has to be pointed out that this visit spearheaded by an intellectual banished by the regime to a then Portuguese colony constituted a truly divisive event, not only because it offered a program evoking the $4^{\text {th }}$ centennial of the first publication of Os Lusíadas that was an alternative to that of the official celebrations simultaneously going on under the auspices of the Governor General ${ }^{3}$, but also, particularly, given the ideas defended by Jorge de Sena during the four conferences he delivered and also in the few but significant interviews he gave to the local media (L. Macedo, 2017a). While linked to Mozambique by the friendship he nurtured by intensely corresponding with some of the intellectuals and artists of then Lourenço Marques, as well as through his collaboration with the poetry magazine Caliban 4 , Jorge de Sena raised awareness to the situation of the Portuguese language in the world - at the time, the world's sixth most widely spoken language and, prospectively, the fourth-ranked by the end of the $20^{\text {th }}$ century - as well as to the problem that, in his opinion, need to be resolved with a sense of urgency: in his words, "the magnitude and weight of our language are largely ignored in the world" 5 , which led, for instance, to difficulty in gaining international recognition of cultural productions in Portuguese 6 .

The then professor at the University of Santa Barbara, in California (where he had arrived after a time in exile in Brazil and a brief passage through Wisconsin) used his

\footnotetext{
${ }^{2}$ The debate being conducted today surrounding the project for building a museum dedicated to expansion/discoveries is a very good illustration of how current the issue is as well as of the simplifying schematics with which it tends to be addressed.

3 The program comprising the official celebrations marking the $4^{\text {th }}$ Centennial of the first publishing of Os Lusíadas, widely documented in the press in Mozambique at the time, essentially consisted of institutional events (gala dinners, gun salutes, ...) that took place over several days.

4 The poetry magazine Caliban was published by João Pedro Grabato Dias (literary alter ego of visual artist António Quadros) and by Rui Knofli from 1971 to 1972, whose central goal was to disseminate Portuguese-language poetry produced at the time, especially that which was produced outside Portugal. Not only Jorge de Sena, but also others collaborated with this magazine, including authors such as José Craveirinha, Rui Nogar and Herberto Hélder (who was living in Angola at the time). Caliban, one of language culture's first few independent projects, was closed down by the Colonial Administration in the month prior to Jorge de Sena's visit.

5 Interview given to the Notícias newspaper dated July $16^{\text {th }}, 1972$, p. 10.

${ }^{6}$ The exception was the work of Camões, especially Os Lusíadas, where Jorge de Sena was one of the world's most renowned experts. By using his vast international expertise, this Portuguese intellectual, in an interview with Rádio Clube de Moçambique on July $19^{\text {th }}, 1972$, showed that Camões' epic poem was the target of interest worldwide, due to its literary value, and not because it was a narrative extolling the glories of Portuguese expansion.
} 
speeches/lectures to point out the causes of the problem, as well as their possible solutions. Portuguese grammarians' appropriation of the language ${ }^{7}$, the propagating of the notion that there are more correct ways than others of speaking the language ${ }^{8}$, the deficient cultural relation between Portugal and Brazil9, as well as not acknowledging the cultural output of the then Portuguese colonies ${ }^{10}$ (which, in his opinion, did not negate the fact that Rui Knopfli was one of the greatest poets and Eugénio Lisboa was one of the biggest literary critics of the Portuguese language of that time) was, in his view, the main reasons for the fragmenting of what he called the "culture of language". On top of the diagnosis, Jorge de Sena used suggestive metaphors and stimulating rhetorical devices to point out those he regarded as being the remedies for those ills: demystifying the historical past and overcoming Portuguese nationalism (L. Macedo, 2017a). This means that the "culture of language", devised by Sena as culture in the Portuguese language, of which nobody is the lawful owner and whose dimension goes beyond the dimension of countries where this language is spoken, cannot be thought out except after strictly revisiting history, capable of restoring the truth of the facts, as well as after Portugal and the Portuguese no longer regard themselves as the privileged epicenter of that culture. Thus, what Sena defended was a "culture of language" founded on the scientific knowledge of history and on an aggregating multiculturalism.

\section{Centrality of the language in the lusophone project}

Portuguese colonialism undoubtedly has its singularities, though these are not the ones usually pointed out. Instead of imagining a predominantly mild colonialism, conducted by a people with a natural evangelizing vocation, free from racism or from exploitation practices, we need to think through its singularity as a result of concrete historical specificities. Hence, the indiscriminate belief in an intrinsically good colonialism should give way to the more realistic view of a peripheral and subordinate colonialism (Santos, 2001). Some of the results of that subordination (low financial capital, absence of a centralized and coherent colonial project, predominance of informal relations, etc.) will constitute arguments for sustaining the lusotropical view, which, however, does not get away from an obvious essentialization. Thus, this is not about rejecting the singularity of Portuguese colonialism or of the post-colonial experience, but about thinking through those phenomena in a more complex way, whether this is founded on the evangelizing vocation, on the availability for crossbreeding, on the natural ability to deal with tropical peoples, or on any other pronouncements with no objective support.

\footnotetext{
7 "It is another truth that, in Portugal, many people are still not convinced: languages belong to those who speak it - not to grammarians" (Notícias, July $16^{\text {th }}, 1972$, p. 10).

8 "Peoples do not speak correctly or incorrectly: they just speak. And, if they didn't speak, then there would be no language!" (Notícias, July $16^{\text {th }}, 1972$, p. 10).

9 "In Portugal, Brazilian authors are not placed in select groups, so that people do not get contaminated by that horrible grammar; nor are Portuguese authors likewise, in Brazil, so as not to think that Portuguese authors are once again colonizing Brazil. Evidently, this is a mutually ridiculous situation" (Interview with Rádio Clube de Moçambique, July 19 ${ }^{\text {th }}, 1972$ ).

10 "I will have the chance to visit the Island of Mozambique, one of the only places - along with Lisbon - where we are certain Camões was" (Notícias, July 16 $6^{\text {th }}, 1972$, p. 10).
} 
The fact that Portuguese is a language shared by peoples scattered throughout the planet is obviously due to the colonial process. Its expansion was, first of all, the result of the sovereign will, and, in that regard, of the attempt to impose the use of a single language in the different parts of an empire. However, the assertion of that common language was also a, shall we say paradoxical, result of the decolonization process and subsequent creation of new political units. Whereas, in the former case, the colonizer's language was an ethnocentric imposition and a strategy of domination of the periphery from the center, in the latter, that same language was the indispensable cement for creating a political unit from a pre-colonial ethnical fragmentation, even if sometimes reinforced by colonial management. Naturally, in every colonized territory, and which currently comprise the CPLP - community of Portuguese-speaking countries -, these general rules were variably enforced. While historical, social and political reasons weigh heavily on these differences, with regard to language policy, the truth is that the convergence was being brought about surrounding Portuguese.

Even surrounding the use of a common language, the consensus is more postulated than effective, not only given the coexistence of the official language with countless national languages, but especially because the language cannot help but comprise a field of dispute; this not only confronts the former metropolis with the new countries, but which also asserts itself as an instrument of power within each space and in relation to the groups comprising it. Given the place it takes up within the lusophone space, it is worth considering the Brazilian case, if only briefly. Throughout the three centuries of Brazil's history as a colony, the coexistence of various languages spoken by the different peoples that lived in its territory was being gradually eliminated until Portuguese definitively asserted itself as a national language. Such a process doubtless constitutes a gigantic glottocide, inseparable from the colonial domination processes, but also from the internal processes that endowed Portuguese language with citizenship. In fact, as Eduardo Lourenço (2004, p. 123) noted, the expansion of the Portuguese language throughout the world "was something ever more important" than the result "of the classical colonizing violence", since "through benevolent chance, the Portuguese, even in their imperial hour, were too weak to 'impose' their language [sic], in the true sense". Merely by appealing to a multidisciplinary view, we could move forward in understanding the historical and cultural processes that led to consolidating a language in a given territory. In what concerns us, we shall leave a brief note on the importance of interculturality in these processes.

Teyssier (2007) remarked that, in the lands of Vera Cruz in the $16^{\text {th }}$ century, populations of indigenous, African or mestizo origin would learn Portuguese spoken by settlers, despite doing so "imperfectly". At the same time, a few settlers, as well as their descendants, also gained a mastery in the tongues of indigenous peoples, thus enabling them to derive dividends from the ease of communicating with others. According to Schwartz (1999, p. 6o),

the Portuguese and mestizos, lay people and clerics who spoke indigenous languages were generally proud of that attribute of theirs; they endeavored 
to proclaim this to the Crown and to other authorities, as this was a neces-

sary and valuable skill in the $16^{\text {th }}$ and in the early $17^{\text {th }}$ centuries.

Simultaneously, the colony saw the development of a general language based on a simplified Tupi and grammarized by Jesuit missionaries which would become a broadly used code by overriding every language in that branch. Regarding this language's origins, Houaiss (1984/1992, p. 53) noticed that "from the start of Gentile catechism, in the $16^{\text {th }}$ century, it became obvious to Jesuit missionaries that their own language would not be used (...) to provide catechism". Thus, communication needs led the missionaries (men who were learned in a knowhow that would later be known as linguistics) to a living practice that emerged from interethnic contacts and which disciplined the various spoken languages among the different groups of Amerindians. The pragmatic possibilities provided by this general language, which entailed interaction not only between Portuguese and indigenous people, but also indigenous people among themselves, brought about their rapid success; this turned Portuguese into a nearly exclusive language of settlers, of urban centers and of other places where Portuguese power was in place.

As Holanda (1936/2010) remarked, for a long time this was the way Portuguese and general language coexisted as communication languages. Brazil then was aware of a bilingualism that increasingly marginalized particular languages preserved by certain local peoples and African languages brought by slaves". Even though Serafim da Silva Neto, in his classic and monumental História da língua portuguesa [History of the Portuguese language] (1952, p. 52), stated that "the history of a language is not a strictly preset plan, it is not an algebra problem", at the same time he presented several trends common to instances of bilingualism. We consider just two of them: a long period where a struggle for supremacy is waged; victory is decided by prestige, the utility value, literary glory and the social status of their speakers. Even without algebra in the mix, that is what happened in $19^{\text {th }}$-century Brazil. As described by Teyssier (2007), several events that occurred during that period would determine the scenario enabling Portuguese to prevail over the general language. On the one hand, the arrival of huge contingents of Portuguese drawn by the discovery of gold and diamond mines caused a swell in the number of speakers of the language of power, with subsequent gains in their useful purpose. On the other hand, in 1753, the Marquis of Pombal enacted a law forbidding the use of the general language and formalized the obligation to use Portuguese in Brazil. The coup de grâce to the general language would finally be given in 1759, when the Jesuits were expelled from Brazilian soil, thereby warding off the colony's chief protectors. By stressing the impact of Rio de Janeiro's "re-lusitanization" process when the court of Portugal's King John VI was moved there in 1808, which brought some 15,000 Portuguese to the empire's new capital, the author concluded that, fifty years after the general language's defenders left, Portuguese had done away with it altogether, with only a few of its traces remaining,

\footnotetext{
"According to Teyssier (2007), the African languages most widely spoken in colonial Brazil were Yoruba (imported from the territory comprising present-day Nigeria) and Kimbundu (imported from Angola). Despite the difficulty in assessing these languages' actual influence on the Portuguese currently spoken in Brazil, it is undeniable that such languages left their marks, namely in terms of vocabulary.
} 
especially in terms of vocabulary. This is the scenario in which, a few years later, in 1822, Brazil became an independent nation. With no other alternative put forth, it was up to Portuguese to become its national language.

Even though Portuguese gained such a status in Brazil since independence in 1822, the truth is, the linguistic issue was not always peaceful among the nation's intellectual elites. Sobrinho (1958/2000) looked at differences surrounding the characteristics specific to the Portuguese language used in Brazil in the first century following independence, identifying three predominant positions, to wit: 1) - affirming the existence of an autonomous Brazilian language, whose staunchest defender is Monteiro Lobato'2; 2) - claiming the formation of a Brazilian dialect from European Portuguese justifying differences in phonetics, prosody and morphology between both forms of speaking; 3 ) - finally, maintaining that the differences between the language spoken in Brazil and in Portugal did not allow for the notion that there were Brazilian dialects or subdialects, as these occurred particularly in pronunciation. However, Sobrinho stresses that the prevalence of Portuguese, in relation to its multiple languages, constituted one of the main arguments for the national unity of a country as immense as Brazil. Truth be told, this is the theory that has prevailed over time, although Brazilian identity continues to counteract the Portuguese identity through different uses of the same language.

\section{IDENTIFYING NARRATIVES: PERSISTENCE AND CHANGE}

As mentioned, while not aspiring to a systemic reading, we will still seek to revisit, in an illustrative manner, the archeology of discursive processes whereby culture and identity define themselves as central arguments in long-term political processes. The temptation of seeing ourselves, as Portuguese, from a conviction of exceptionality has a long history and has been widely commented (Vecchi, 2010). This set the tone, for example, for Eduardo Lourenço (1992) to write Psicanálise mítica do destino português [Mythical psychoanalysis of Portuguese destiny], a text that became a benchmark. Other authors and texts, preceding and subsequent to the one we have evoked, also addressed this topic, such that the notion of the Portuguese exception has become a sort of black hole, which absorbs everything - even critical and deconstructionist considerations end up being integrated into a meta-narrative, generating new updated versions of the exception, of which a known best-seller by philosopher José Gil (2004) is an example. One of the vital parts of this secular claim of exceptionality was the colonial/imperial project, that, in the different configurations being assumed since the $15^{\text {th }}$ century, did not get away from narratives founded on the notion of exceptionality. Some are quite, such as the dream of

\footnotetext{
${ }_{12}$ Monteiro Lobato (1882-1948), one of Brazil's main authors of his time, achieved huge success in the field of children's and youth literature. Sítio do Pica-Pau Amarelo ranks among his most well-known works (Dicionário das Literaturas Portuguesa, Galega e Brasileira [Dictionary of Portuguese, Galician and Brazilian Literatures], 1960). A staunch nationalist who resisted any kind of "Europeanization", Lobato defended the existence of an autonomous Brazilian language, separate from Portuguese. However, as Sobrinho (1958/2000, p. 66) notes, his theory conforms to a "somewhat simplistic and precarious syllogism", since it hinged on the notion that, just as Portuguese emerged from a corrupted version of Latin, so, too, the Brazilian arose from a corrupted form of the Portuguese.
} 
the Quinto Império [Fifth Empire] which, incidentally, has been undergoing renewal; other are more recent, but still no less central to the debate, such as the entire conceptual structure of lusotropicalism.

The messianic notion of a Quinto Império, originally formulated by Fr. António Vieira in the $17^{\text {th }}$ century, and later re-updated by Fernando Pessoa and by Agostinho da Silva, in the $20^{\text {th }}$ century, illustrates well the way the notion of exceptionality ended up heavily structuring the narrative surrounding who we are. Its roots are found in the biblical myth of the interpretation given by Daniel regarding an enigmatic dream that Nebuchadnezzar, king of Babylon, had. According to said interpretation, after four earthly and perishable kingdoms, which translated the fall and breakdown of Humanity, God's will would cause the emergence of a universal and timeless fifth kingdom to save it. The Portuguese Jesuit took that Bible passage and reinterpreted it within the context of a world which, for the first time, presented a planetary dimension, putting together the proper conditions of extent and duration for the emergence of a new and definitive level, that is, the Quinto Império [Fifth Empire]. Prior to the Portuguese voyages of the $15^{\text {th }}$ and $16^{\text {th }}$ centuries, no empire could extend to the whole Earth, or ensure the completeness and eternity that had been put forth by Daniel. With those conditions in place, the Quinto Império would emerge to unite all peoples under the same civilizational level through the evangelization undertaken by the Portuguese, thus overcoming Humanity's crisis. Since said crisis originated in Europe's old world, Fr. António Vieira focused that fifth kingdom on Brazil, a still pristine part of the world and where so much still remained undiscovered (Franco, 2007). These are the formulations in which Calafate (2006, p. 61), in Vieira's thinking, interprets a "dream of universal harmony and peace" emerging from a conception "of the ecumenical history heavily impregnated by movement, transformation, newness", in which the Portuguese took on the role of a chosen people on the horizon of human action, toward another future: that of a new and latest level, where human beings come out of themselves to live for the world.

This providential rehabilitation of Humanity would be resumed by Fernando Pessoa, though with more abstract contours, with its insertion lost in geography and its possibility of application in historical times. Thus, in Pessoa, the Quinto Império was constituted as a myth' ${ }^{13}$ or a vision of the soul (Franco, 2007), in a radical criticism of the existence of those living happy in their small house and small backyard'4. In this regard, Calafate (2006) noted that, in Pessoa, the elevation of the soul conducive to Quinto Império goes by way of aspiring to the "fondness of the times", a place above the averageness, reserved solely to saints and heroes.

\footnotetext{
${ }^{13}$ Sinde (quoted in Pessoa, 1934/2007, p. 5) notes that Fernando Pessoa sought to revived the myth as a way of understanding national history. In this regard, the author states: "Fernando Pessoa understood the myth as the true enabler of History (...), thus giving it meaning, while bestowing reality on the destiny of nations and individuals".

${ }^{14}$ This critique by Fernando Pessoa is clearly expressed in the poem "Quinto Império", contained in the work Mensagem (Message), of which some of the most illustrative verses are presented: "Triste de quem vive em casa / Contente com o seu lar / Sem que um sonho, no erguer da asa / (...) /Ser descontente é ser homem / Que as forças cegas se domem / Pela visão que a alma tem!" (Sad of those living at home / Happy with their home / Without a dream, when raising the wing / (...) / Being dissatisfied means being a man / That blind strength is tamed / By the vision that the soul have!) (Pessoa, 1934/2007, p. 89).
} 
With the re-reading of this myth by Agostinho da Silva, we go back to the need for a historical project that re-updates the geographical implementation and the civilizational reflection. The view of the thinker on the world's fifth age gravitated around the choices of modern human beings, as this is the fourth of those ages. Modernity could victimize Humanity in the long fratricidal struggle characterizing history or, alternatively, could elevate it in the fullness of a universal civilization, with no famines or oppressions (Franco, 2007). Despite dealing with a choice to be made, Agostinho's every thought asserts the primacy of life over death, and so the future is not supposed to prefigure an inert age. Rather, the planetary-scale fifth age, which would bring together all peoples, would rely on a decisive contribution from the Portuguese-speaking community, whose mission would be to unify the world by the spirit. Seeking to summarize Agostinho da Silva's proposal on the last of the levels of Humanity, stated Freixo (2007, p. 24):

in this new age, the Portuguese language would play a vital role, as it is spoken in every part of the globe and representing the symbol of the Portuguese expansion that laid the foundation for building the "new world," of the "Kingdom of the Spirit". In this new order, Brazil would play a vital role, as the nation would carry in itself the elements of the real Portugal, that archaic Portugal that was lost with the nation's historical failure. To him, in his utopia, Brazil is the fulfillment of the dream of the Quinto Império: it is Camões' Ilha dos Amores (Island of Loves), the Non-Place capable of being the center of a new civilization, as this is the meeting point of various cultures, where the crossbreeding favored tolerance and moderation.

Right off the bat, Agostinho da Silva's refounding of Vieira's myth stems from modifying historical circumstances. Whereas, in Vieira, Portugal can fully assume the role of key player in the Utopian project, the time when Agostinho da Silva was an author no longer allows for this. In any event, in both authors, the Quinto Império projects the ideal of a final, perennial and happy age, where Portugal and Brazil fulfill the messianic mission of uniting Humanity under a single civilizational level. Between the aggregation surrounding an evangelization bearing Portugal's mark (Vieira) or buoyed on shared language and cultures constituting a de-territorialized lusitaniousness (Agostinho da Silva), we have evidence of a narrative continuity anchoring a mythical vision of a collective identity.

Lusotropicalismo, coined by Gilberto Freyre, constitutes another significant reference in the argument of Portuguese exceptionality, while decisively contributing toward this mythical narrative. With regard to the final stretch of Portuguese colonial history and ideologically appropriated by the Estado Novo regime, it's important to understand, first of all, that lusotropicalism was a theory that started off by thinking through and legitimizing the nation of Brazil, underlining a cultural unit overlapping the political unit, thus counteracting the suspicion in the possibilities of a new country, at the time regarded as dangerously crossbreeded. This origin of lusotropicalist theory is relevant, to the extent that it springs forth in the periphery and needs to be accommodated in the lengthy foundational process of a diffuse and continent-sized nation (Ribeiro, 1995); thus, this is regarded as appropriated and transmuted in a legitimizing narrative of an old metropolis 
beset by the winds of European decolonization (Cunha, 2015b). At this point, more than repeating the Brazilian sociologist's arguments here, we deem it useful to highlight this symbolic reversal of the center/periphery order, as this points out the singularity of the Portuguese colonial project on a different plane from what is normally commented; such a project is peripheral and subordinate to the major European powers.

As concerns lusotropicalism's contribution to the debate surrounding a lusophone identity, it's important to bear in mind the great deal of criticism incurred at the hands of Portuguese and Brazilian intellectuals, even though it cannot help but also be regarded as one of the few interpretative theories of Portuguese colonialism (Sousa, 2001). Freyre's central argument hinges on valuing the processes of "racial" and cultural crossbreeding in areas colonized by the Portuguese - initially thinking of Brazil but then extending the positive assessment to other territories - maintaining the originality of the Portuguese colonial project; this is envisioned according to a development "not within a strict exclusivity of race or even of culture, but by means of constant interpenetration of various cultural values and of abundant crossbreeding" (Freyre, 1940, p. 12). The criticisms made to this reported that racial crossbreeding was always more fallocratic that democratic, and that the integration of African, Amerindian or oriental cultural elements in the habits of today's Portuguese-speaking peoples respected predominantly economic interests thus clarifying regimes acculturation that were not entirely reciprocal. By contrast with these criticisms, the notion of exceptionality kept on being underpinned, despite being nuanced: achieved crossbreeding and hybridism, without having been politically projected, constitute perennial legacies of many of the societies founded in areas formerly under Portuguese colonial control.

What underlies these two metanarratives (and it's in this regard that they concern us here) is the chance to discuss the notion of cultural identity from the relation between universality and particularism. In the case of Vieira and Agostinho da Silva, we are not faced with a particularism seeking to universalize itself; in the case of Freyre, it's about putting forth the possibility of absorbing diversity from a single identity. Both narratives require belief in an exceptionality to become convincing, and so it's important to analytically consider the concept. The problem that exceptionalism raises obviously does not lie in the singularity of each nation relative to its counterparts. The geographical and historical contexts determine objective singularities that are more or less expressive. The problem is raised when the claim of exception is made based on moral judgments: our colonization was not only different but also morally better. For starters, this is a problem because it thinks through identities from an essentialist matrix, while outlining a genuine, timeless collective soul. It was conservative thinking, which we can politically situate to the right, that ended up appropriating this notion of exception overlaid with moral content, while a look over to the left, more critical and deconstructionist, rejected essentialism and, by extension, also the notion of exception. While following another path, post-colonial trends, as well, were committed to rejecting particularisms, preferring to deal with the colonial phenomenon across the board, in keeping with a line of thought founded by Edward Said (1978). Somehow, and forgiven us by using a everyday folk, this matter "risks throwing 
out the baby with the bathwater". While not denying the singularities, what we are dealing with involves looking at historically situated differences, extricating them from moral contents, which always end up leading to unwanted essentialisms.

\section{BETWEEN CONVERGENCE AND DIVERGENCE: THE POWER OF NARRATIVES}

Lusophony stands out from other post-colonial experiences, not as a result of any essence, but given the historical circumstances that determined the nature of relations between the metropolis and colonized territories and among the different groups facing each other. The material and symbolic domination was historically precarious and haphazard, always relying more on agents involved than on a consolidated power structure. It is precisely the frailty of Portuguese colonialism, as revealed in the comparison with other colonial regimes, that made Lusophony useful for thinking through the challenges that are inherent to present-day intercultural communication, namely the risk of post-colonial relations disguising the perpetuation of asymmetric power relations (Cabecinhas \& Cunha, 2017; I. Macedo, 2016; L. Macedo, 2017b; Martins, 2017).

To this end, we should be able to resist seeing Lusophony as a place of conciliation, an illusory meeting point for peoples that their lot fell to Portuguese colonialism. What matters is that it be regarded as a crossroads for narratives fueled by history as much as from social memory. In this regard, Lusophony can be a meeting point but also a divergent point, that is, a crossroad for converging and diverging narratives. Let us take up what was said earlier regarding lusotropicalism: academic theory, built up with a domestic intention, that is, which sought to explain Brazilian identity and to legitimize a unity on diversity; this ended up being appropriated and redirected to another task: justifying the continuity of Portugal's colonial domination in Africa. We take this up in order to point out that the theory developed by Freyre fed off of a narrative content which, as such, transcends Brazil's border, and can have free rein in Portugal or even in other colonial territories. While the theory evolved and which, in its reading, there were variations in emphasis or even in meaning, such dynamics did not entail rejection, but, rather, an accommodation of narrative. Thus, over the decades, especially in Brazil and in Portugal, Lusotropicalism, while remaining an imaginative projection, can serve as a recognizable thread that created networks and webs of unity and strife.

In this same regard concerning the existence of a diffuse, contradictory and conflicting narrative space, but nonetheless generating dialectics, we can call up other examples. Hearken to the way Christianity, which was left as a colonial legacy in Timor, grew after Portugal left the territory, while being reinterpreted as one of the matrix roots of its claim for independence from Indonesia (Sousa, 2001). At another level, the colonial/liberation war, an obvious point of tension and conflict, also constituted a narrative node around which shared but diverging memories are structured (Cabecinhas \& Cunha, 2017). Another dense set of common narratives are given by migratory experiences, which crosses the entire space that Lusophony comprises (Abadia, Cabecinhas, Cunha $\&$ Macedo, 2018). In the case of Portugal, the weight of unskilled emigration, even to 
countries that were former colonies, is illustrative of the singularity of Portuguese colonialism in the aforementioned points - subordination and periphery. Looked at differently, however, this gains unexpected meaning, becoming a narrative recourse available for building shared memories, where Lusophony is not just a space for economic convergence, not even the recovered expression of a conventional relation between center and periphery. By contrast, one that could be a polycentric, complex space traversed by multiple signs, capable of bringing together different peoples and distinct national experiences surrounding an effective interculturality (Lopes, 2015; Martins, 2015).

\section{A BRIEF NOTE FOR AN INCONCLUSIVE END}

Here, we take up the distinction, reported to Raymond Williams, between universalism, which rests on an understanding of culture as civility, and the value of particularism, which regards culture as a product and producer of identity. We consider that it is precisely to the border between these two categories that we need to ring the debate, especially at a time when the entire space - physical, cultural, ethnic, financial... - appears to be invested by categories associated with the notion of border. Ambivalence, blending and liminality, are among those categories, just as the notion of artificiality, which is counteracted and naturalized through discursiveness and practice. Whereas political borders bear the scars of history, lines of demarcation which, over the course of time, and more in some cases than in others, have become more profound, creating effectively distinct territories, the same process can be observed in cultural borders, whether they are thought through from what has become a national tongue, or report to other historical and cultural relations.

As with every border, differences are enhanced or blurred even in these cases. The debate between singularity and exceptionality, which we mentioned above, need to be thought out starting from this premise, as a way of understanding how the objectification of the former is mistaken for the inaccuracy of the latter. In fact, whereas singularity can be objectively regarded, as stemming from concrete and measurable historical and social processes, exceptionality hearkens to diffuse criteria, often associated with an assumed identity-related essence. Therefore, we need to distinguish the two planes, the only way to overcome the impasse between criticism of identity-related essentialism and the possibility of deepening the concrete experiences of interculturality. Somehow, this is what we tried to do, whether by appealing to the archeology of some of the central narratives that founded an assumed culture and Portuguese-speaking identity, and by summoning a unique experience of reflection surrounding this topic, specifically that of Jorge de Sena in Mozambique, and even suggesting the existence of a set of narratives that traversed the Portuguese-speaking space interconnecting its different peoples. The attempt to replace exceptionality with singularity and to do so via the heuristic value of concrete situations, evidently does not mean exempting from criticism such experiences of interculturality. The idea here is to look into a set of relationship possibilities that are interstitially outlined, that is, in the diffuse space left vacant by formal relations among nation-states. 
Speaking of Lusophony, just as speaking of Francophony, of Hispanophony or of the Commonwealth, means addressing the same phenomenon, though expressed in different modulations (Margarido, 2000). Reporting to representations and contents that outline formal and informal links between former metropolises and the former colonies, such expressions contain both the possible post-colonial consensus and criticism thereof. In some cases, as is the case with the CPLP, there is a formal instance politically managing that consensus; however, we cannot lose sight of the fact that the debate extends well beyond that surface. Beyond the agreement surrounding a language policy; and also beyond any understandings with regard to means of economic cooperation, to the notion of Lusophony will continue to correspond to feelings, experiences, memories, expectations. Prevailing in a few cases are lines of convergence, and divergence is highlighted in others; such a difference is of little importance if what is at issue is not the construction of a common identity, but, rather, mutual recognition.

In this way, the sharing of unique experiences, which are only recognizable by the common language and by traces of memory and history - in some cases of cooperation and in other of conflicts - with which a patrimony can be founded with no homeland nor center, belonging to all who build their identities by speaking the Portuguese language.

Translation: Traduções Técnicas do Minho, Lda.

\section{REFERENCES}

Abadia, L., Cabecinhas, R., Macedo, I. \& Cunha, L. (2018). Interwoven migration narratives: identity and social representations in the lusophone world. Identities - Global Studies in Culture and Power, 25(3), 339357. DOI: $10.1080 / 1070289 X .2016 .1244062$

Beck, U. (2006). Qu'est-ce le cosmopolitisme? Paris: Éditions Aubier.

Cabecinhas, R. \& Cunha, L. (2017). Da importância do diálogo ao desafio da interculturalidade. In R. Cabecinhas \& L. Cunha (Eds.), Comunicação intercultural: perspectivas, dilemas e desafios (pp. 7-12). Vila Nova de Famalicão: Húmus.

Cabecinhas, R., Macedo, I., Jamal, C. \& Sá, A. (2018). Representations of European colonialism, African resistance and liberation struggles in Mozambican history curricula and textbooks. In K. van Nieuwenhuyse \& J. P. Valentim (Eds.), The colonial pasts in history textbooks. Historical and social psychological perspectives (pp. 217-237). Charlotte, NC: Information Age Publishing.

Calafate, P. (Ed.) (2006). Portugal como problema. Séculos XVII e XVIII, da obscuridade profética à evidência geométrica (Volume II). Lisboa: Fundação Luso-Americana e Público.

Catroga, F. (2005). Nação, mito e rito. Religião civil e comemoracionismo. Fortaleza: Edições Nudoc-UFC/ Museu do Ceará.

Chakrabarty, D. (2000). Histórias de minorias, passados subalternos. In M. R. Sanches (Ed.), Deslocalizar a Europa. Antropologia, arte, literatura e história na pós-colonialidade (pp. 209-230). Lisboa: Livros Cotovia.

Cunha, L. (2015a). Liminaridade e descentramento: identidades lusófonas e suas narrativas. In M. L. Martins (Ed.), Lusofonia e interculturalidade - promessa e travessia (pp. 113-127). Vila Nova de Famalicão: Húmus. 
Cunha, L. (2015b). O Luso no Trópico, ou por que não pode Olinda ser Olanda. In M. Cardão \& C. Castelo (Eds.), Gilberto Frepre. novas leituras do outro lado do Atlântico (pp. 61-78). São Paulo: Edusp.

Dicionário das Literaturas Portuguesa, Galega e Brasileira (1960). Direção de Jacinto do Prado Coelho. Porto: Livraria Figueirinhas.

Eagleton, T. (2000). A ideia de cultura. Lisboa: Temas \& Debates.

Ferro, M. (2004). Comment on raconte l'histoire aux enfants à travers le monde (nouvelle édition revue). Paris: Éditions Payot.

Franco, A. C. (2007). Nótula sobre o Quinto Império em Agostinho da Silva. Revista Convergência Lusíada, 23, 55-62. Retrieved from http://www.realgabinete.com.br/portalweb/portals/o/documentos/revista23.pdf

Freixo, A. (2007). A língua portuguesa como utopia: Agostinho da Silva e o ideal da comunidade lusófona. Revista Convergência Lusíada, 23, 21-27. Retrieved from http://www.realgabinete.com.br/portalweb/ portals/o/documentos/revista23.pdf

Freyre, G. (1940). O mundo que o português criou: aspectos das relações sociais e de cultura do Brasil com Portugal e as colônias portuguesas. Rio de Janeiro: José Olympio.

Gil, J. (2004). Portugal, hoje. O medo de existir. Lisboa: Relógio d’Água.

Holanda, S. B. (1936/2010). Raízes do Brasil. São Paulo: Companhia das Letras.

Houaiss, A. (1984/1992). O Português no Brasil. Rio de Janeiro: Editora Revan.

Lopes, A. J. (2015). Política linguística: terra de ninguém, terra de todos. Notas a partir de um Posto de Observação Moçambicano. In M. L. Martins (Ed.), Lusofonia e interculturalidade - promessa e travessia (pp. 197-226). Vila Nova de Famalicão: Húmus.

Lourenço, E. (1992). O labirinto da saudade. Psicanálise mítica do destino português. Lisboa: Dom Quixote.

Lourenço, E. (2004). A Nau de Ícaro seguido de imagem e miragem na lusofonia. Lisboa: Gradiva.

Macedo, I. (2016). Os jovens e o cinema português: a (des)colonização do imaginário? Comunicação e Sociedade, 29, 271-290. DOI: 10.17231/comsoc.29(2016).2420

Macedo, L. (2013). Da diversidade do mundo ao mundo diverso da lusofonia: a reinvenção de uma comunidade geocultural na sociedade em rede. Doctoral thesis in Communication Sciences - Specialization in Intercultural Communication, University of Minho, Braga, Portugal. Retrieved from http://repositorium. sdum.uminho.pt/handle/1822/28851

Macedo, L. (2017a). Desmitificar o passado e ultrapassar o nacionalismo para o desenvolvimento de uma cultura de língua portuguesa: o contributo de Jorge de Sena. In E. B. Rosa \& M. E. Prado (Eds.), Atas do XII Colóquio Internacional Tradição e Modernidade no Mundo Ibero-Americano. Rio de Janeiro: Rede Sirius; Porto, Portugal.

Macedo, L. (2017b). Sobre o “Jardim das Delícias” como modelo de análise dos processos de comunicação intercultural. Comunicação e Sociedade, 31, 225-238. DOI: 10.17231/comsoc.31(2017).2614

Margarido, A. (2000). A lusofonia e os lusófonos: novos mitos portugueses. Lisboa: Edições Universitárias Lusófonas.

Martins, M. L. (2015). Lusofonias - reinvenção de comunidades e combate linguístico-cultural. In M. L. Martins (Ed.), Lusofonia e interculturalidade - promessa e travessia (pp. 7-23). Vila Nova de Famalicão: Húmus. 
Martins, M. L. (2017). Comunicação da ciência, acesso aberto do conhecimento e repositórios digitais o futuro das comunidades lusófonas e ibero-americanas de Ciências Sociais e Humanas. In M. L. Martins (Ed.), A internacionalização das comunidades lusófonas e ibero-americanas de Ciências Sociais e Humanas o caso das Ciências da Comunicação (pp. 19-58). Vila Nova de Famalicão: Húmus.

Neto, S. S. (1952). História da língua portuguesa. Rio de Janeiro: Livros de Portugal.

Pessoa, F. (1934/2007). Mensagem. Porto: Porto Editora.

Portes, A. (2006). Imigração e metrópole: reflexões sobre história urbana. In Estudos sobre as migrações contemporâneas. Transnacionalismo, empreendedorismo e a segunda geração (pp. 19-45). Lisboa: Fim de Século.

Ribeiro, D. (1995). O povo brasileiro. A formação e o sentido do Brasil. São Paulo: Editora Schwarcz.

Said, E. (1978). Orientalismo. O Oriente como invenção do Ocidente. São Paulo: Editora Schwarcz.

Santos, B. S. (2001). Entre Próspero e Caliban: colonialismo, pós-colonialismo e inter-identidade. In M. I. Ramalho \& A. S. Ribeiro (Eds.), Entre ser e estar: raízes, percursos e discursos da identidade (pp. 24-85). Porto: Afrontamento.

Schwartz, S. B. (1999). Segredos internos. Engenhos e escravos na sociedade colonial. São Paulo: Companhia das Letras.

Sen, A. (2007). Identidade e violência. A ilusão do destino. Lisboa: Tinta da China.

Sobrinho, B. L. (1958/2000). A língua portuguesa e a unidade do Brasil. Rio de Janeiro: Nova Fronteira.

Sousa, I. C. (2001). The Portuguese colonization and the problem of East Timorese Nationalism. Lusotopie, 183-194. Retrieved from https://www.persee.fr/doc/luso_1257-0273_2001_num_8_1_1439

Teyssier, P. (2007). História da língua portuguesa. São Paulo: Martins Fontes.

Vecchi, R. (2010). Excepção Atlântica. Pensar a literatura da guerra colonial. Porto: Afrontamento.

Wacquant, L. (2014). Marginalidade, etnicidade e penalidade na cidade neoliberal. Uma cartografia analítica. Tempo Social, 26(2), 139-164. DOI: 10.1590/S0103-20702014000200009

Williams, R. (1958). Culture and society. Londres: Penguin Books.

\section{BIOGRAPHICAL NOTES}

Luís Cunha holds a PhD in Anthropology, integrated member of CRIA and professor of the Department of Sociology of the Institute of Social Sciences - University of Minho. His research has been oriented around several themes, such as national identities, social memory in the border contexts, colonialism and postcolonialism, and more recently on the crisis of financial systems and their representations.

ORCID: https://orcid.org/oooo-0002-9940-9265

Email: Imcunha@ics.uminho.pt

Address: Instituto de Ciências Sociais, Universidade do Minho, Campus de Gualtar, 4710-057 Braga, Portugal 
Lurdes Macedo holds a PhD in Communication Sciences at University of Minho (Portugal). She was a member of the project "Identity narratives and social memory: the (re)making of Lusophony in intercultural contexts". Nowadays, she is researcher on Intercultural Communication and Communication for Development with a pos-doctoral Grant supported by FCT. She was editor of Anuário Internacional de Comunicação Lusófona (2010 and 2011) and Interfaces da Lusofonia (2014) co-editor. She published more than 20 papers in national and international scientific journals as first author and as a co-author. She was member of several organizing and scientific committees of international conferences. She was Professor in Education School at Instituto Politécnico de Viseu (2009-2012) and she is a Professor at Universidade Lusófona do Porto since 2008.

ORCID: https://orcid.org/0000-0002-1577-1313

Email:mlmacedo7ı@gmail.com

Address: Centro de Estudos de Comunicação e Sociedade, Instituto de Ciências Sociais, Universidade do Minho, Campus de Gualtar, 4710-057 Braga

Rosa Cabecinhas holds a PhD in Communication Sciences (Social Psychology). Currently, she is Head of the Doctoral Program in Cultural Studies at the University of Minho.

ORCID: https://orcid.org/0000-0002-1491-3420

Email: cabecinhas@ics.uminho.pt

Address: Centro de Estudos de Comunicação e Sociedade, Instituto de Ciências Sociais, Universidade do Minho, Campus de Gualtar, 4710-057 Braga

* Submitted: 15.05 .2018

* Accepted: 11.07.2018 